\title{
Coumarin dye with ethynyl group as $\pi$-spacer unit for dye sensitized solar cells
}

\author{
Érica Torres a ${ }^{\mathrm{a}}$, Sara Sequeira ${ }^{\mathrm{a}}$, Pedro Parreira ${ }^{\mathrm{b}}$, Paulo Mendes ${ }^{\mathrm{c}}$, Tiago Silva ${ }^{\mathrm{c}, \mathrm{d}}$, \\ Killian Lobato ${ }^{\mathrm{e}}$, Maria João Brites ${ }^{\mathrm{a}, *}$ \\ a LNEG-UES Unidade de Energia Solar, Estrada do Paço do Lumiar, 22, 1649-038 Lisboa, Portugal \\ ${ }^{\mathrm{b}}$ SUPA, School of Physics E Astronomy, University of Glasgow, G12 8QQ Glasgow, Scotland, United Kingdom \\ ${ }^{c}$ Centro de Química-Universidade de Évora (CQE), Rua Romão Ramalho, 59, 7000-671 Évora, Portugal \\ ' Centro de Química Estrutural, Faculdade de Ciências, Universidade de Lisboa, Campo Grande, 1049-016 Lisboa, Portugal \\ e Instituto Dom Luis, Faculdade de Ciências, Universidade de Lisboa, Campo Grande, 1049-016 Lisboa, Portugal
}

\section{A R T I C L E I N F O}

\section{Article history:}

Received 20 March 2015

Received in revised form 8 May 2015

Accepted 16 May 2015

Available online 21 May 2015

\section{Keywords:}

Coumarin dyes

Alkyne bridge

Dye-sensitized solar cells

EIS analysis

Charge recombination

Dye aggregation

\begin{abstract}
A B S T R A C T
C1-LEN coumarin dye, containing an ethynyl conjugated bridge was tested as a new chromophore for dye-sensitized solar cells (DSSCs). Investigation on the relationship of dye structure, optical properties, electrochemical properties and performance of DSSCs is described. The C1-LEN-sensitized solar cells showed an overall conversion efficiency of $2.2 \%\left(J_{\mathrm{SC}}=6.11 \mathrm{~mA} / \mathrm{cm}^{2}, V_{\mathrm{OC}}=547 \mathrm{mV}, \mathrm{FF}=0.66\right)$, which corresponds to $68 \%$ of N719-based device efficiency, fabricated under similar conditions. Electrochemical impedance spectroscopy (EIS) analysis reveals that charge recombination at the nanocrystalline $\mathrm{TiO}_{2} /$ dye/redox electrolyte interface is similar for C1-LEN and N719 sensitized solar cells, i.e., charge recombination is not the factor limiting the performance of C1-LEN device.
\end{abstract}

(C)2015 Elsevier B.V. All rights reserved.

\section{Introduction}

Organic chromophores for dye sensitized solar cells (DSSC) have drawn the attention of many research groups in the last decade. The wide variety of structures and easy modification of organic dyes provides potential for molecular design, with the introduction of substituents onto the chromophore skeletons allowing control of not only their photophysical and electrochemical properties, but also of their stereochemical structures. Donor- $\pi$-bridge-Acceptor $(D-\pi-A)$ system is the basic feature for most metal free organic dyes because an efficient electron transfer from donor to acceptor can happen upon photo-excitation of the sensitizer [1,2].

A lot of studies have focused on conjugated bridges such as vinyl, phenyl and thiophenyl, but only few focuses on the influence of a triple bond as a $\pi$-spacer unit in the concept of D- $\pi-A$ structure [3-7]. The alkyne $\pi$-bridge has been utilized for conjugated donor-acceptor systems because it is a rigid and straight for conducting electrons and at the same time reduces charge recombination [4,5]. Based on reported studies [6], a triple

\footnotetext{
* Corresponding author. Tel.: +351 210924600.

E-mail address: mjoao.brites@lneg.pt (M.J. Brites).
}

bond geometrically close to the electron donor moiety is more electronegative than a double bond. This weakens the electronwithdrawing ability of electron acceptor because of the opposite dipole moment of triple bond and electron acceptor, resulting in a blue-shift in the absorption spectra. However, changing the position of the triple bond closer to the electron acceptor will strengthen the electron-withdrawing ability of the electron acceptor because of the identical dipole moment of triple bond and electron acceptor, resulting in a red-shift in the absorption spectra.

Recombination of injected electrons in the conduction band (CB) of $\mathrm{TiO}_{2}$ with dye cations and triiodide $\left(\mathrm{I}_{3}{ }^{-}\right)$ions in the electrolyte, leading to lower short-circuit current densities (Jsc) and open-circuit voltage $\left(V_{\mathrm{OC}}\right)$, depends strongly on the molecular structure of the dye sensitizer and the molecular orientation and arrangement of the dyes on the $\mathrm{TiO}_{2}$ surface. The most effective strategy to retard charge recombination between the injected electrons and the dye cations is the formation of a wide spatial separation between the moieties with positive charge density on the excited dye and the $\mathrm{TiO}_{2}$ surface and it seems that preventing the dyes from lying on the $\mathrm{TiO}_{2}$ surface is a key consideration $[1,8,9]$. Charge recombination between injected electrons in the conduction band of $\mathrm{TiO}_{2}$ and $\mathrm{I}_{3}{ }^{-}$ions in the electrolyte can be 